\title{
Long-term experiments on chernozem soil in the University of Debrecen
}

\author{
PÉTER PEPÓ \\ University of Debrecen, Faculty of Agricultural, Environmental and Food \\ Sciences, Debrecen, Hungary \\ pepopeter@agr.unideb.hu
}

\section{Summary}

The impact of agrotechnical management practices (nutrient and water supply, crop rotation, crop protection, genotype) on the yields of winter wheat and maize and on the soil water and nutrient cycles was studied in long-term experiments set up in 1983 in Eastern Hungary on chernozem soil. The long-term experiments have shown that nitrogen fertilizer rates exceeding the $\mathrm{N}$-optimum of winter wheat resulted in the accumulation of $\mathrm{NO}_{3}-\mathrm{N}$ in the soil. Winter wheat varieties can be classified into four groups based on their natural nutrient utilization and their fertilizer response. The fertilizer responses of wheat varieties depended on crop year (6.5-8.9 $\mathrm{t} \mathrm{ha}^{-1}$ maximum yields in 2011-2015 years) and the genotypes (in 2012 the difference was $\sim 3 \mathrm{tha}^{-1}$ among varieties). The optimum $\mathrm{N}(+\mathrm{PK})$ doses varied between $30-150 \mathrm{~kg} \mathrm{ha}^{-1}$ in different crop years. In maize production fertilization, irrigation and crop rotation have decision role on the yields. The efficiency of fertilization modified by cropyear (in dry 891-1315 $\mathrm{kg} \mathrm{ha}^{-1}$, in average $1927-4042 \mathrm{~kg} \mathrm{ha}^{-1}$, in rainy cropyear $2051-4473 \mathrm{~kg}^{-1}$ yield surpluses of maize, respectively) and crop rotation (in monoculture $1315-4473 \mathrm{~kg}^{-1}$, in biculture 924-2727 kg ha-1 and triculture 891-2291 kg ha-1 yield surpluses of maize, respectively). The optimum fertilization could improve the water use efficiency in maize production.

Our long-term experiments gave important ecological and agronomic information to guide regional development of sustainable cropping systems.

Keywords: long-term experiments, chernozem soil, crop year, agrotechnical elements, wheat, maize

\section{Introduction}

Plant growth, yield and yield stability in field crop production are determined by a complex interaction of environmental, biological and agrotechnical management factors. The impacts and interactions between these factors can be studied most effectively in long-term experiments.

The oldest long-term experiments were set up 130-175 years ago (Rothamsted, 1843; Grignon, 1875; Illinois, 1876; Halle, 1878 etc.). Such long-term experiments provide valuable data on the effects of agrotechnical management practices on the yield of the given crop, on the 
associated changes in the soil properties, the impact of environmental factors (climate) and any resulting environmental impacts/risks (Johnston, 1997; Körschens, 2006; Hejcman and Kunzová, 2010; Pepó, 2015).

The increasing demands of the world for food, feed, industrial raw materials, biofuels etc., means that more crop production products, in terms of quantity and quality, are also required. In the last half century, the land area of the world covered by arable production has not changed dramatically (it is $\sim 10.5 \%, F A O, 2017$ ) and it is expected to remain at the same level in the future. The increasing demands can be fulfilled only by intensification of crop production. In parallel, intensive crop production also has to meet the demands of sustainability and environmental protection. Within a given environment, the most important farmercontrolled factors of wheat yield are genotype, crop management (Bell et al., 1995; Duvick and Cassmann, 1999) and their interaction (Pepó, 2005).

Long-term experiments are essential tools to assess and develop effective management practices for sustainable production and environmental impact (Rasmussen et al., 1998; Richter et al., 2007). In the sustainable intensification of crop production, yields are increased without adverse environmental impacts and without the cultivation of more land (Baulcombe et al., 2009). Godfray et al. (2010) have focused on the importance of reducing the "yield gap" - this is the difference between realised productivity and the best that can be achieved using current genetic material and available technologies and management.

Traditional cereal production uses a lot of external inputs to achieve high yields (Hole et al., 2005). Hungarian crop production is cerealoriented one. Proportion of cereals (small grains and maize) takes about $70 \%$ of Hungarian arable land. In sustainable cereal production nutrient supply, fertilization is a key agrotechnical element (Jordan et al., 1997; Oehl et al., 2004; Keller et al., 2012), but the crop rotation, irrigation, plant density, weed control (Berzsenyi et al., 2000; Vad et al., 2007; Pepó, 2017) have important role, too. The yield-losses and yield fluctuation of cereals caused by crop year (climate change) depended on soil conditions, the stress-tolerance of genotypes and the agrotechniques.

The long-term experiments set up at Látókép Experimental Station, near Debrecen, Hungary, more than 30 years ago provide an opportunity to determine the individual and interactive effects of the different agrotechnical management treatments on the vegetative and generative development of the major cereal crops (wheat, maize) and the consequent yield and crop quality. From the data of these long-term experiments, cause and effect relationships leading to changes in the yield and crop quality of yields can also be determined under varying weather conditions. The experimental results also enable the study of the 
environmental impacts arising from crop production, thereby creating a basis for the development of sustainable crop models. The aim of our research was to study the effects of the major agrotechnical management factors (nutrient and water supply, crop rotation, plant density, crop protection) on winter wheat and maize (growth parameters, yield, crop quality) and on soil nutrient $(\mathrm{N}, \mathrm{P}, \mathrm{K})$ and water cycles.

\section{Material and methods}

The long-term experimental site, within the Látókép Experimental Station, is located in Eastern-Hungary (region Hajdúság), $15 \mathrm{~km}$ from Debrecen ( $\mathrm{N} 47^{\circ} 33^{\prime}$ E $21^{\circ} 27^{\prime}$ ). The long-term experimental site is characterized by continental climatic conditions. The average total annual precipitation is $565 \mathrm{~mm}$ and average annual yearly mean temperature is $9.84{ }^{\circ} \mathrm{C}$.

The soil is a calcareous chernozem with a specific plasticity index $\left(\mathrm{K}_{\mathrm{A}}\right)$ of 43 , and nearly neutral $\mathrm{pH}\left(\mathrm{pH}_{\mathrm{KCl}}=6.46\right)$. When the long-term experiments were set up the humus content of the topsoil was $2.76 \%(0-$ $0.2 \mathrm{~m}$ upper soil layer) and the total depth of the humus-enriched horizon was about $0.8 \mathrm{~m}$. The phosphorus and potassium supplies can be regarded as medium (AL- $\mathrm{P}_{2} \mathrm{O}_{5} 133 \mathrm{mg} \mathrm{kg}^{-1}$ ) and good (AL- $\mathrm{K}_{2} \mathrm{O} 240 \mathrm{mg}$ $\left.\mathrm{kg}^{-1}\right)$, respectively. Water holding properties of the soil are very favourable for crop production. Total water storage capacity is $808 \mathrm{~mm}$ in the 0-2 m layer with an available water of $513 \mathrm{~mm}$ in the 0-2 $\mathrm{m}$ layer of which $342 \mathrm{~mm}$ is readily available. The water table is at 8-10 meters depth.

Two long-term experiments were set up in 1983.

Long-term experiment No.1 - Wheat variety fertilizer response testing

The treatments are as follows:

- fertilization;

- crop rotation;

- genotypes.

The plots are $10 \mathrm{~m}^{2}$ and the experiment design is a split-split-plot with 4 replications. The total area of the experiment is $\sim 3$ ha.

Long-term experiment No.2 - Polyfactorial experiment for different crop models

The treatments are as follows:

- crop rotation;

- fertilization;

- water supply;

- specific agronomic factors.

The plots are $46 \mathrm{~m}^{2}$ and the experiment design is a split-split-plot with 4 replications. The total area of the experiment is $\sim 10.5$ ha. 


\section{Results and discussion}

Our long-term experimental results proved that weather conditions (mainly the rainfall quantity and its distribution) strongly modified the yields of winter wheat genotypes even on chernozem soil characterized by excellent water- and nutrient husbandry. In the average of wheat varieties and crop years the yield was $7631 \mathrm{~kg} \mathrm{ha}^{-1}$ but the yields varied depending on the crop years (Table 1). The minimum yield was in 2013 (6514 kg ha-1) and we got the maximum yield in 2015 (8921 kg ha-1). The winter wheat genotypes could differently adapt to the crop year. According to our long-term experimental data we could state that the differences among the varieties were about $3 \mathrm{t} \mathrm{ha}^{-1}$ in the same agrotechnical conditions (in 2012 the yields varied between $6075-8919 \mathrm{~kg}$ $\mathrm{ha}^{-1}$ ). The crop year (mainly the water supply during the vegetation period) can modify the optimum $\mathrm{N}+\mathrm{PK}$ doses, too. In crop year characterized by average water supply the optimum $\mathrm{N}+\mathrm{PK}$ doses varied between $\mathrm{N}=90-150 \mathrm{~kg} \mathrm{ha}^{-1}+\mathrm{PK}$ and in crop year after very mild winter the $\mathrm{N}_{\text {opt }}+\mathrm{PK}$ dropped down to $\mathrm{N}=30-60 \mathrm{~kg}^{-1}+\mathrm{PK}$ (because of very high mineralization of organic matter in the chernozem soil).

Table 1. Fertilizer response of winter wheat genotypes in different crop years (Debrecen, chernozem soil, 2011-2015)

\begin{tabular}{|c|c|c|c|c|c|c|}
\hline Variety & $\begin{array}{c}2011 \\
\left(\mathrm{~N}_{\text {opt }}\right)\end{array}$ & $\begin{array}{c}2012 \\
\left(\mathrm{~N}_{\text {opt }}\right)\end{array}$ & $\begin{array}{c}2013 \\
\left(\mathrm{~N}_{\text {opt }}\right)\end{array}$ & $\begin{array}{c}2014 \\
\left(\mathrm{~N}_{\text {opt }}\right)\end{array}$ & $\begin{array}{l}2015 \\
\left(\mathrm{~N}_{\text {opt }}\right)\end{array}$ & $\begin{array}{c}\text { Averag } \\
\text { e }\end{array}$ \\
\hline GK Öthalom & $6819_{(150)}$ & $6175_{(150)}$ & $5983(150)$ & $8713_{(30)}$ & 8862 (150) & 7310 \\
\hline Pannonikus & 8123 & $8139_{(150)}$ & $6576_{(150)}$ & $7996(30)$ & 8864 (90) & 7940 \\
\hline Euclide & $9586(150)$ & $8919_{(150)}$ & $7590(150)$ & - & - & 8698 \\
\hline GK Csillag & - & $7263(150)$ & $6562(150)$ & $8350(60)$ & $9150(150)$ & 7831 \\
\hline Bitop & - & $6075(150)$ & $6089_{(120)}$ & $6663(30)$ & - & 6276 \\
\hline GK Békés & - & $7917_{(150)}$ & $6281_{(120)}$ & $7915(30)$ & 8809 (90) & 7731 \\
\hline Average & 8176 & 7415 & 6514 & 7927 & 8921 & 7631 \\
\hline Yield interval ( $\mathrm{t} \mathrm{ha}^{-1}$ ) & $6.8-9.6$ & $6.1-8.9$ & $6.0-7.6$ & $6.7-8.4$ & $8.8-9.2$ & $6.3-8.7$ \\
\hline Min-Max (\%) & $83-117$ & $82-120$ & $92-117$ & 84-105 & 99-103 & $82-114$ \\
\hline Interval of yield fluctuation (\%) & 34 & 38 & 25 & 21 & 4 & 32 \\
\hline Interval of $\mathrm{N}_{\text {opt }}\left(\mathrm{kg} \mathrm{ha}^{-1}\right)$ & $90-150$ & $120-150$ & $120-150$ & $30-60$ & $90-150$ & $90-128$ \\
\hline $\mathrm{LSD}_{5 \%}$ & 457 & 355 & 600 & 674 & 614 & - \\
\hline
\end{tabular}

Results of our long-term experiment carried out for 30 years proved that the fertilizer response of the different winter wheat varieties (Figure 1) can be determined by the following parameters:

- Natural nutrient utilization ability (indicated by the level of the variety's control yield);

- Fertilizer utilization ability (yield surplus of fertilization);

- Realized maximum yield (under specific ecological and agrotechnical conditions); 
- Fertilizer requirement (optimum N+PK dosage of the given variety).

Figure 1. Fertilizer response of winter wheat varieties (Debrecen)

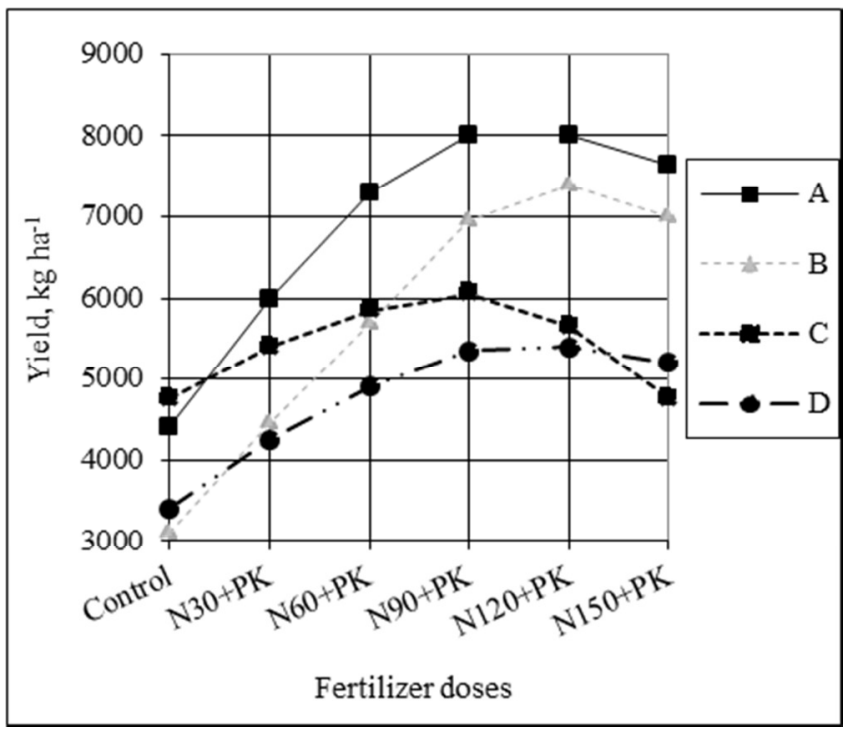

The types of winter wheat varieties according to their fertilizer response are as follows:

Type A: modern type (combines the advantages of the extensive and intensive types); it has an excellent utilization of both the natural soil nutrient stock and the fertilizers.

Type B: intensive type, it has traditionally weak natural nutrient utilizing ability, but high fertilizer response.

Type C: extensive type, it has traditionally excellent natural nutrient utilizing ability, but moderate fertilizer response.

Type D: unfavourable type, this type cannot utilize effectively either the soil nutrients or the fertilizers.

Our long-term experimental data proved that the fertilization of wheat resulted good yield surpluses on chernozem soil characterized by excellent natural nutrient stock (Table 2). The yield surpluses of wheat varied between $2659 \mathrm{~kg} \mathrm{ha}^{-1}\left(2013 / 2014\right.$ crop year) and $6020 \mathrm{~kg} \mathrm{ha}^{-1}$ (2015/2016 crop year). The yields of control treatment proved the excellent natural nutrient avaibility of chernozem soil $\left(1816 \mathrm{~kg} \mathrm{ha}^{-1}\right.$ and $\left.5897 \mathrm{~kg} \mathrm{ha}^{-1}\right)$. The other meteorological parameters could modify the yield surplus of wheat genotypes (in 2013 the strong and long frosting period in March decreased the yields; in 2014 the very mild winter period accelerated the $\mathrm{N}$-mineralization in chernozem soil). 
Table 2. Effect of crop year on the control and maximum yield of winter wheat (average of varieties, Debrecen, 2010-2017)

\begin{tabular}{lcccccc}
\hline Crop year & $\begin{array}{c}\text { Control } \\
\text { yield } \\
\mathrm{kg} \mathrm{ha}^{-1}\end{array}$ & $\begin{array}{c}\text { Maximum } \\
\text { yield } \\
\mathrm{kg} \mathrm{ha}^{-1}\end{array}$ & $\begin{array}{c}\text { Yield- } \\
\text { surplus } \\
\mathrm{kg} \mathrm{ha}^{-1}\end{array}$ & $\begin{array}{c}\text { Rainfall in } \\
\text { veg. period } \\
(\mathrm{mm})\end{array}$ & $\begin{array}{c}\text { Rainfall deviation } \\
\text { from 30 year } \\
\text { average }(\mathrm{mm})\end{array}$ & $\begin{array}{c}\mathrm{N}_{\text {opt }} \\
(+\mathrm{PK}) \\
\mathrm{kg} \mathrm{ha}^{-1}\end{array}$ \\
\hline $2010 / 2011$ & 4023 & 8043 & 4020 & 340.9 & -60.0 & 133 \\
$2011 / 2012$ & 3906 & 7303 & 3397 & 320.7 & -80.2 & 144 \\
$2012 / 2013$ & 1816 & 6674 & 4858 & 480.2 & +79.3 & 145 \\
$2013 / 2014$ & 5897 & 8556 & 2659 & 284.0 & -116.9 & 49 \\
$2014 / 2015$ & 4662 & 9024 & 4362 & 350.9 & -50.0 & 110 \\
$2015 / 2016$ & 3927 & 9947 & 6020 & 561.7 & +160.81 & 115 \\
$2016 / 2017$ & 5226 & 8028 & 2802 & 379.6 & -21.3 & 133 \\
\hline
\end{tabular}

Wheat is a sensitive arable crop to agroecological and agrotechnical factors. Our multifactorial long-term experimental data (between 1986 and 2017) proved that the effects of fertilization were different depending on the crop rotation and the weather of crop year. In Eastern Hungary characterized by continental climate the precipitation quantity and its distribution are the decisive agroecological factor on chernozem soil. The effects of crop year were significant on the yields of wheat in different (bi- and triculture) crop rotation (Table 3).

Table 3. Effect of crop year, crop rotation and fertilization on the yield of wheat in long-term experiment (Debrecen, chernozem soil, 1986-2017)

\begin{tabular}{|c|c|c|c|c|c|c|}
\hline \multirow[b]{2}{*}{ Crop rotation } & \multicolumn{6}{|c|}{ Yield (kg ha-1) } \\
\hline & \multicolumn{2}{|c|}{$\begin{array}{l}\text { Dry crop year } \\
9 \text { years }(28 \%)\end{array}$} & \multicolumn{2}{|c|}{$\begin{array}{c}\text { Average crop year } \\
18 \text { years }(56 \%)\end{array}$} & \multicolumn{2}{|c|}{$\begin{array}{c}\text { Rainy crop year } \\
5 \text { years }(16 \%)\end{array}$} \\
\hline $\begin{array}{l}\text { Control } \\
\mathrm{N}_{\text {opt }}+\mathrm{PK}^{* *}\end{array}$ & $\begin{array}{l}1892 \mathrm{f} \\
5590 \mathrm{~cd}\end{array}$ & $3698^{*}$ & $\begin{array}{l}2516 \text { ef } \\
8029 \mathrm{ab}\end{array}$ & $5513^{*}$ & $\begin{array}{l}3162 \mathrm{e} \\
5419 \mathrm{~cd}\end{array}$ & $2257^{*}$ \\
\hline \multicolumn{7}{|l|}{ Triculture (after peas) } \\
\hline $\begin{array}{l}\text { Control } \\
\mathrm{N}_{\text {opt }}+\mathrm{PK}^{* * *}\end{array}$ & $\begin{array}{l}4426 \mathrm{de} \\
7279 \mathrm{~b}\end{array}$ & $2853^{*}$ & $\begin{array}{l}5763 \mathrm{~cd} \\
8600 \mathrm{a}\end{array}$ & $2837^{*}$ & $\begin{array}{l}4885 \mathrm{~cd} \\
6190 \mathrm{a}\end{array}$ & $1305^{*}$ \\
\hline
\end{tabular}

We obtained the strongest effect of crop year in biculture (the yields of wheat varied between $1892-3162 \mathrm{~kg} \mathrm{ha}^{-1}$ in control and $5419-8029 \mathrm{~kg} \mathrm{ha}^{-1}$ in $\mathrm{N}_{\text {opt }}+\mathrm{PK}$, respectively). In diversed crop rotation (triculture) the yieldfluctuations of wheat were less (in control $4426-5763 \mathrm{~kg} \mathrm{ha}^{-1}$, in $\mathrm{N}_{\mathrm{opt}}+\mathrm{PK}$ $6190-8600 \mathrm{~kg} \mathrm{ha}^{-1}$, respectively). The efficiency of fertilization was modified by crop year and crop rotation. The highest yield surpluses of wheat were obtained in average crop year in different crop rotation, but the efficiency of nutrient supply was much higher in biculture $(5513 \mathrm{~kg}$ $\left.\mathrm{ha}^{-1}\right)$ comparing with triculture $\left(2837 \mathrm{~kg} \mathrm{ha}^{-1}\right)$. The optimum $\mathrm{N}(+\mathrm{PK})$ 
doses were much lower $\left(\mathrm{N}_{\mathrm{opt}}=50-100 \mathrm{~kg} \mathrm{ha}^{-1}+\mathrm{PK}\right)$ in triculture than in biculture $\left(\mathrm{N}_{\mathrm{opt}}=150-200 \mathrm{~kg} \mathrm{ha}^{-1}+\mathrm{PK}\right)$ because of peas forecrop.

The results of the polyfactorial long-term experiment showed (Table 4) that increasing the intensity of plant protection resulted in the decrease of the values of infection with leaf, stem and ear diseases. Averaged over 2013-2016, the increase of fertiliser doses significantly increased infection level. At the same time, in the case of crop rotation, there was no difference between the infection values of biculture and triculture. In the case of the various plant protection technologies, compared to extensive technology, average plant protection significantly decreased infection, while there was a moderate difference between average and intensive plant protection technologies in both crop rotations.

Table 4. Effects of crop rotation, fertilization and crop protection on the infections (\%) of winter wheat (Debrecen, chernozem soil, non irrigated, 2013-2016)

\begin{tabular}{|c|c|c|c|c|}
\hline \multirow{2}{*}{$\begin{array}{c}\text { Crop protect. } \\
\text { Fert. }\end{array}$} & \multicolumn{4}{|c|}{ Biculture } \\
\hline & Powdery mildew & Helminthosporium & Leaf rust & Yellow rust \\
\hline \multicolumn{5}{|l|}{ Extensive } \\
\hline$\varnothing$ & 4 & 9 & 2 & 6 \\
\hline $\mathrm{N}_{\text {opt }}+\mathrm{PK}$ & 14 & 25 & 12 & 26 \\
\hline \multicolumn{5}{|l|}{ Average } \\
\hline$\varnothing$ & 3 & 6 & 2 & 5 \\
\hline $\mathrm{N}_{\mathrm{opt}}+\mathrm{PK}$ & 11 & 19 & 9 & 13 \\
\hline \multicolumn{5}{|l|}{ Intensive } \\
\hline$\varnothing$ & 2 & 4 & 1 & 1 \\
\hline $\mathrm{N}_{\mathrm{opt}}+\mathrm{PK}$ & 6 & 13 & 5 & 4 \\
\hline \multirow[t]{2}{*}{$\begin{array}{l}\text { LSD }_{5} \% \\
\end{array}$} & 2 & 4 & 3 & 5 \\
\hline & \multicolumn{4}{|c|}{ Triculture } \\
\hline \multicolumn{5}{|l|}{ Extensive } \\
\hline$\varnothing$ & 8 & 13 & 6 & 10 \\
\hline $\mathrm{N}_{\mathrm{opt}}+\mathrm{PK}$ & 16 & 23 & 12 & 15 \\
\hline \multicolumn{5}{|l|}{ Average } \\
\hline$\varnothing$ & 5 & 8 & 4 & 5 \\
\hline $\mathrm{N}_{\mathrm{opt}}+\mathrm{PK}$ & 13 & 20 & 10 & 11 \\
\hline \multicolumn{5}{|l|}{ Intensive } \\
\hline$\varnothing$ & 3 & 6 & 2 & 2 \\
\hline $\mathrm{N}_{\text {opt }}+\mathrm{PK}$ & 7 & 13 & 6 & 5 \\
\hline $\mathrm{LSD}_{5 \%}$ & 3 & 5 & 2 & 4 \\
\hline
\end{tabular}

The longer duration of these experiments enable the study of the most important material processes (water and nutrient cycle) in the crop production space. In the course of testing the fertilizer response of winter wheat varieties, the dynamics of the chernozem soil's water stock during the vegetation period of winter wheat is determined. The yield of winter wheat was strongly determined by the soil's water stock and the amount of available water in the soil during the phenophases (earing-flowering) critical for the yield formation of winter wheat (Figure 2). 
Figure 2. Effect of crop year and crop rotation on the water-husbandry of chernozem soil and the yields of winter wheat in long-term experiment (Debrecen, Hungary)
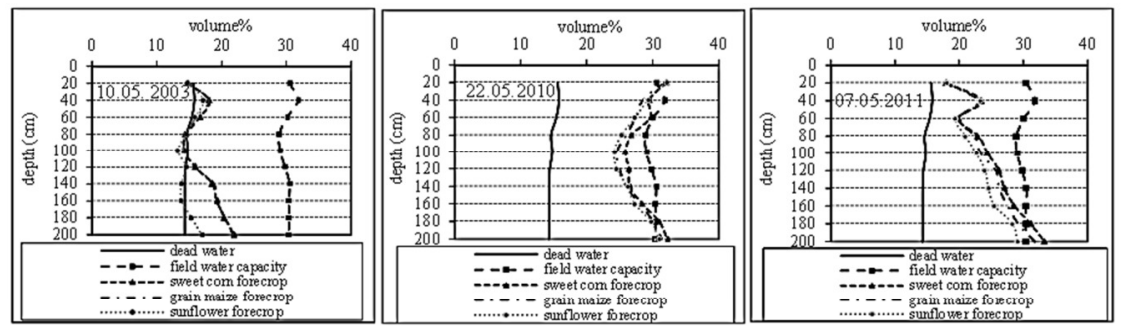

\begin{tabular}{|c|c|c|}
\hline \multicolumn{3}{|c|}{ Dry crop year } \\
\cline { 1 - 2 } \multicolumn{2}{|c|}{$\begin{array}{c}\text { Yield } \\
\left(\mathrm{kg} \mathrm{ha}^{-1}\right)\end{array}$} & $\begin{array}{c}\text { Yield surplus } \\
\text { of fertilization } \\
\left(\mathrm{kg} \mathrm{ha}^{-1}\right)\end{array}$ \\
\cline { 1 - 2 }$\varnothing$ & $\mathrm{N}_{\text {op }}+\mathrm{PK}$ & 795 \\
\hline 3447 & 4242 & \\
\hline
\end{tabular}
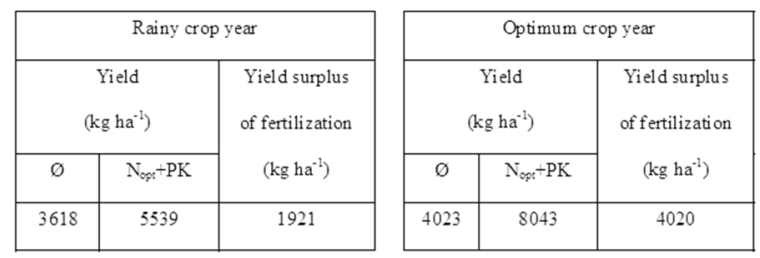

Our long-term experimental results proved (Figure 3) that $\mathrm{N}$ fertilization exceeding the agro-ecological demand of winter wheat increases the $\mathrm{NO}_{3}-\mathrm{N}$ content of the soil. This $\mathrm{NO}_{3}-\mathrm{N}$ accumulation layer increased with time (100 mg kg-1 in 1995 and $275 \mathrm{mg} \mathrm{kg}^{-1}$ in 2000), and even under continental climate conditions (prone to draught) it shifted gradually to the bottom soil layers $(0.8-1.4 \mathrm{~m}$ in 1995 and $1.2-2.2 \mathrm{~m}$ in 2000).

Maize is a sensitive field crop to agroecological and agrotechnical factors.

Especially important key-elements are the nutrient- and water supply and crop rotation in sustainable maize production. Our polifactorial longterm experimental data proved that the effects of fertilization were different depending on the crop rotation and the weather of crop year.

The effects of crop year were significant on the yields of maize in every crop rotation (Table 5). The yields of control (non fertilized), varied between $3743-7279 \mathrm{~kg} \mathrm{ha}^{-1}$ in dry crop years, $6305-9577 \mathrm{~kg} \mathrm{ha}^{-1}$ in average crop years and 7538-10 $221 \mathrm{~kg} \mathrm{ha}^{-1}$ in rainy crop years, respectively. The maize yields were in optimum fertilizer treatments in the same crop year types between 5058-8203 kg ha-1, $10457-12168 \mathrm{~kg} \mathrm{ha}^{-1}$ and 12 521-13 014 $\mathrm{kg} \mathrm{ha}^{-1}$, respectively. We obtained the strongest effect of crop year in monoculture. The efficiency of fertilization was modified by crop year and crop rotation. The biggest fertilization effects were in monoculture and lowest ones were in triculture. So the appropriate crop rotation can reduce the $\mathrm{N}_{\text {opt }}+\mathrm{PK}$ fertilizer doses (in mono- $\mathrm{N}_{180}+\mathrm{PK}$, in bi- $\mathrm{N}_{120}+\mathrm{PK}$, in triculture $\left.\mathrm{N}_{60}+\mathrm{PK}\right)$. 
Figure 3. Effect of $\mathrm{N}$-fertilization on the $\mathrm{NO}_{3}-\mathrm{N}$ accumulation of chernozem soil in long-term experiment (Debrecen, Hungary)
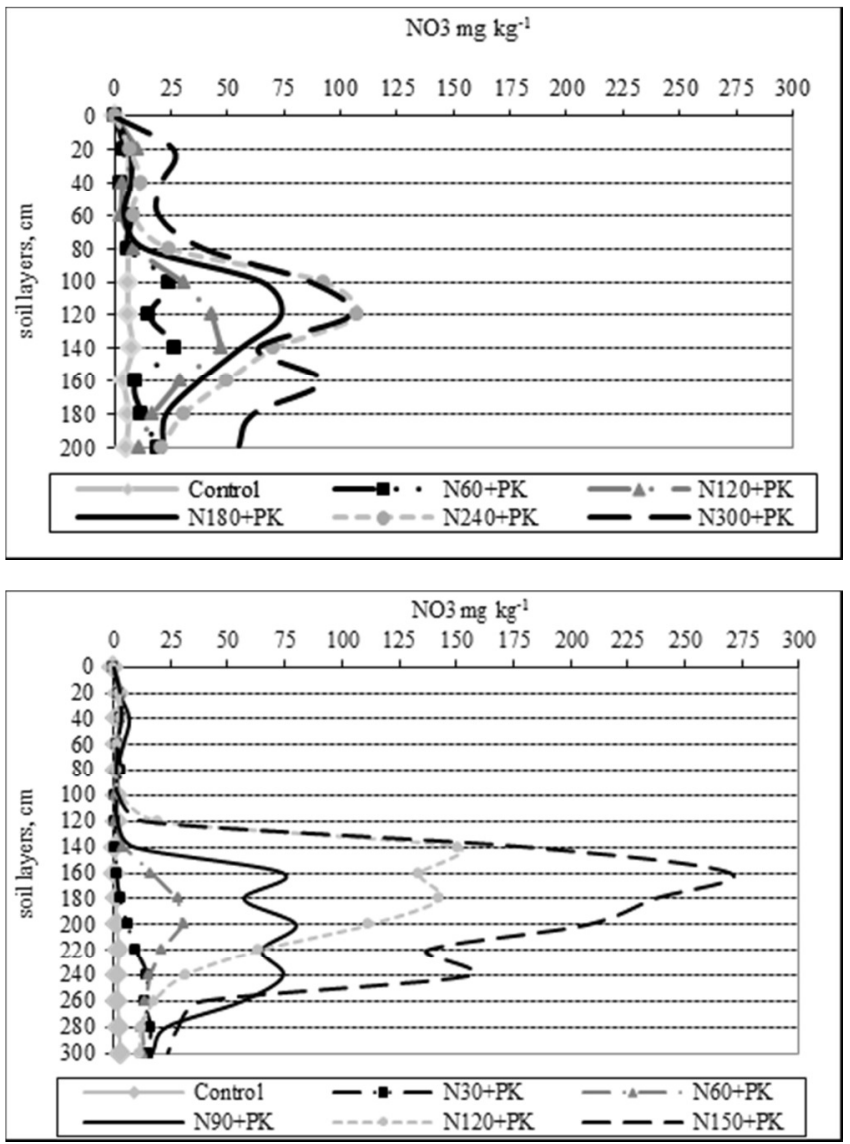

Table 5. Effect of crop year, crop rotation and fertilization on the yield of maize in longterm experiment (Debrecen, chernozem soil, 1986-2017)

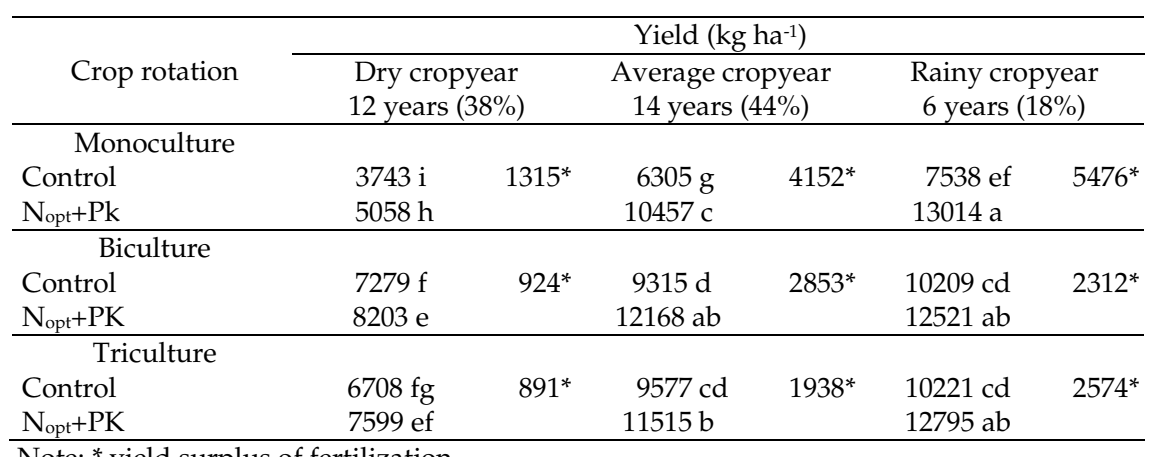

Note: * yield surplus of fertilization. 


\section{Conclusions}

Our long-term experiments proved that we have to harmonize the ecological, biological and agrotechnical factors to increase the nutrientand water-use efficiency and decrease the harmful environmental effects in wheat production. According to our findings there were huge differences among the maximum yields and the optimum $\mathrm{N}+\mathrm{PK}$ doses of winter wheat genotypes. The wheat varieties differently responded to the $\mathrm{N}+\mathrm{PK}$ fertilizer doses and they differently utilized the natural nutrient sources of chernozem soil. The yields of wheat varieties varied between 6075-9586 kg ha-1 and the $\mathrm{N}_{\text {opt }}+\mathrm{PK}$ doses fluctuated between $\mathrm{N}=30-150$ $\mathrm{kg} \mathrm{ha} \mathrm{h}^{-1}+\mathrm{PK}$ depending the crop year (mainly water supply) and genotypes. So under climatic change the optimum fertilization is a keyelement to change the conventional wheat production into a sustainable one (Austin, 1999; Pepó, 2007; Maye et al., 2015; Bala and Sikder, 2017).

Monitoring the sustainability of wheat production needs different indicators (Barrios and Sarte 2008). The nutrient- and water-use efficiency were modified by crop year, crop rotation and fertilization. We obtained the highest yield surpluses of wheat in average crop year, in diversified crop rotation with using less $\mathrm{N}_{\text {opt }}+\mathrm{PK}$ doses $(\mathrm{N}=50-100 \mathrm{~kg}$ ha-1+PK) comparing with the dry and rainy crop years, simplified crop rotation (biculture) simiraly to Dobermann (2005), Noureldin et al. (2013) and Khatri et al. (2017).

In maize production fertilization, irrigation and crop rotation have decision role on the yields. The efficiency of fertilization modified by crop year (in dry 891-1315 $\mathrm{kg} \mathrm{ha}^{-1}$, in average 1938-4152 $\mathrm{kg} \mathrm{ha}^{-1}$, in rainy crop year 2312-5476 kg ha-1 yield surpluses of maize, respectively) and crop rotation (in monoculture $1315-5476 \mathrm{~kg} \mathrm{ha}^{-1}$, in biculture $924-2853 \mathrm{~kg}$ $\mathrm{ha}^{-1}$ and triculture $891-2574 \mathrm{~kg} \mathrm{ha}^{-1}$ yield surpluses of maize, respectively). The optimum fertilization could improve the water use efficiency in maize production.

In the long-term winter wheat fertilization experiment, the excellent nutrient supplying capacity of the chernozem soil was proved even 30 years after starting the experiment (Berzsenyi et al., 2000; Babulicová, 2008) and also the differences between the wheat genotypes in their fertilizer responses were verified. Based on the fertilizer response, the winter wheat varieties were classified into four groups. In a polyfactorial long-term experiment, the significant effect of the year (mainly that of water supply) was found both in winter wheat and in maize. In contrast with other long-term experiments (Schellberg and Hüging, 1997; Yang et al., 2014), a high level of yield was obtained even in the control treatment on the chernozem soil in our experiment (winter wheat: $1892-4885 \mathrm{~kg} \mathrm{ha}^{-1}$, maize: 2685-9602 $\mathrm{kg} \mathrm{ha}^{-1}$ ). The yield-increasing effect of fertilization was 
influenced both by the year and the crop rotation. Maximum yields of winter wheat and maize varied from 7.3 to $8.6 \mathrm{t} \mathrm{ha}^{-1}$ and from 10.0 to 13.0 $\mathrm{t}$ ha-1, respectively.

\section{Acknowledgement}

The publication is supported by the EFOP-3.6.3.-VEKOP-16-2017-00008 project. The project is co-financed by the European Union and the European Social Fund.

\section{References}

Austin, R. B. (1999): Yield of wheat in the United Kingdom: recent advances and prospects. Crop Science. 39. 6: 1604-1610.

Babulicová, M. (2008): Influence of fertilization on winter wheat in crop rotations and in long-term monoculture. Plant Soil Environment. 54: 190-196.

Bala, P.-Sikder, S. (2017): Growth of Wheat Genotypes Influenced by Heat Stress. International Journal of Environment, Agriculture and Biotechnology. 2. 4: 1863-1878.

Barrios, E. B.-Sarte, G. Ma. F. (2008): Monitoring sustainable agriculture in Southeast Asia. International Journal of Sustainable Development \& World Ecology. 15. 2: 95-102.

Baulcombe, D.-Crute, I.-Davies, B.-Dunwell, J.-Gale, M.-Jones, J. J.-Sutherland, W.Toulmin, C. (2009): Reaping the benefits: science and the sustainable intensification of global agriculture. London, UK: The Royal Society, Policy document 11/09.

Bell, M. A.-Fischer, R. A.-Byerlee, D.-Sayre, K. (1995): Genetic and agronomic contributions to yield gains: a case study for wheat. Field Crops Research. 44: 55-65.

Berzsenyi, Z.-Györffy, B.-Lap, D. (2000): Effect of crop rotation and fertilisation on maize and wheat yields and yield stability in a long-term experiment. European Journal of Agronomy. 13: 225-244.

Dobermann, A. (2005): Nitrogen use efficiency: State of the art. IFA International Workshop on Enhanced-Efficiency Fertilizers. Frankfurt. 28-30 June. International Fertilizer Industry Association (FIA). Paris. France. 1-16.

Duvick, D. N.-Cassman, K. G. (1999): Post-green revolution trends in yield potential of temperature maize in the north-central United States. Crop Science. 39: 1622-1630.

Godfray, H. C. J.-Beddington, J. R.-Crute, I. R.-Haddal, L.-Lawrence, D.-Muir, J. F.Pretty, J.-Robinson, S.-Thomas, S. M.-Toulmin, C. (2010): Food security: the challenge of feeding 9 billion people. Science. 327: 812 .

Hejcman, M.-Kunzová, E. (2010): Sustainability of winter wheat production on sandy-loamy Cambisol in the Czech Republic: Results from a long-term fertilizer and crop rotation experiment. Field Crops Research. 115: 191-199. 
Hole, D. G.-Perkins, A. J.-Wilson, J. D.-Alexander, H. I.-Grice, P. V.-Evans, A. D. (2005): Does organic farming benefit biodiversity? Biological Conservation. 122: 113-130.

Johhston, E. A. (1997): The value of long-term experiments in agricultural, ecological and environmental research. Advances in Agronomy. 59: 291-333.

Jordan, V. W. L.-Hutcheon, J. A.-Donaldson, G. V.-Farmer, D. P. (1997): Research into and development of integrated farming systems for less-intensive arable crop production: experimental progress (1989-1994) and commercial implementation. Agriculture Ecosystems and Environment. 64. 2: 141-148.

Keller, M.-Oberson, A.-Annaheim, K. E.-Tamburini, F.-Maeder, P.-Mayer, J.Frossard, E.-Buenemann, E. K. (2012): Phosphorus forms and enzymatic hydrolyzability of organic phosphorus in soils after 30 years of organic and conventional farming. Journal of Plant Nutrition and Soil Science. 175. 3: 385393.

Khatri, N.-Chalise, D. R.-Rawal, N. (2017): Short term effect of crop residue and different nitrogen levels on grain yield of wheat under rice-wheat system. International Journal of Environment, Agriculture and Biotechnology. 2. 4: 1689-1693.

Körschens, M. (2006): The importance of long-term field experiments for soil science and environmental research - a review. Plant Soil Environment. 52 Special Issue: $1-8$.

Maye, J.-Gunst, L.-Mäder, P.-Samson, M. F.-Carcea, M.-Narducci, V.-Thomsen, I.Dubois, D. (2015): Productivity, quality and sustainability of winter wheat under long-term conventional and organic management in Switzerland. European Journal of Agronomy. 65: 27-39.

Noureldin, N. A.-Saudy, H. S.-Ashmawy, F.-Saed, H. M. (2013): Grain yield response index of bread wheat cultivars as influenced by nitrogen levels. Annals of Agricultural Science. 58: 147-152.

Oehl, F.-Frossard, E.-Fliessbach, A.-Dubois, D.-Oberson, A. (2004): Basal organic phosphorus mineralization in soils under different farming systems. Soil Biology and Biochemistry. 36: 667-675.

Pepó, P. (2005): New issues in sustainable wheat production. [In: Ciobanu et al. (eds.) Tehnologii de cultura pentru grau si porumb.] 17-27.

Pepó, P. (2007): The role of fertilization and genotype in sustainable winter wheat (Triticum aestivum L.) production. Cereal Res. Commun. 35. 2: 917-920.

Pepó, P. (2015): Use of long-term experiments to determine the impact of agrotechnical practices in wheat (Triticum aestivum L.) and maize (Zea mays L.) production. Aspects of Applied Biology. 128: 231-237.

Pepó, P. (2017): Role of agrotechnical elements in sustainable wheat and maize production. Columella - Journal of Agricultural and Environmental Sciences. 4. 1: 59-64.

Rasmussen, P. E.-Goulding, K. W. T.-Brown, J. R.-Grace, P. R.-Janzen, H. H.Korschens M. (1998): Long-term agroecosystem experiments: assessing agricultural sustainability and global change. Science. 282: 893-896.

Richter, D. D.-Callaham, M. A.-Powlson, D. S.-Smith, P. (2007): Long-term soil experiments: keys to managing Earth's rapidly changing ecosystems. Soil Science Society of America Journal. 71: 266-279. 
Schellberg, J.-Hüging, H. (1997): Yield development of cereals, row crops and clover in the Dikopshof long-term fertilizer trial from 1906 to 1996. Arch. Acker Pflanzenbau Bodenkd. 42: 303-318.

Vad, A.-Zsombik, L.-Szabó, A.-Pepó, P. (2007): Critical crop management factors in sustainable maize (Zea mays L.) production. Cereal Res. Commun. 35. 2: 12531256.

Yang, X. Y.-Sun, B. H.-Zhang, S. L. (2014): Trends of yield and soil fertility in a long-term wheat-maize system. Journal of Integrative Agriculture. 13. 2: 402414 . 